\title{
How Do Inflation Rate, BI Rate, and Balance of Trade Directly Affect IDR to USD Exchange Rate and Indirectly Affect IDX Composite Index in Initial Stage of Covid-19 Outbreak?
}

\author{
Hilarius Bambang Winarko ${ }^{1}$, Julius Caesare Wahono ${ }^{1}$, Yuniningsih ${ }^{2} \&$ Sri Tunggul Pannindriya $^{3}$ \\ ${ }^{1}$ Sampoerna University, Indonesia \\ ${ }^{2}$ University of Pembangunan Nasional Veteran East Java, Indonesia \\ ${ }^{3}$ LSPR Communication \& Business Institute, Indonesia \\ Correspondence: Hilarius Bambang Winarko, Sampoerna University, Indonesia.
}

Received: August 14, 2020

doi:10.5430/rwe.v12n1p56
Accepted: November 5, 2020

Online Published: January 3, 2021

URL: https://doi.org/10.5430/rwe.v12n1p56

\begin{abstract}
This study is trying to fill the research gap by understanding how several important financial variables interplay and affect the macroeconomic indicators, especially in developing country like Indonesia during the financial crisis period caused by the unexpected and sudden Covid- 19 pandemic outbreak. The purpose of this research is to determine the direct effect of the inflation rate, Bank Indonesia (BI) rate, and Balance of Trade on the movement of Indonesia Rupiah (IDR) currency stability against US Dollar (USD) and indirect impact to the Indonesia Stock Exchange (IDX) Composite index in Indonesia during the initial stage of the pandemic outbreak. To achieve the research objectives, this study uses the Rupiah exchange rate against USD and IDX Composite index as the dependent variables, while the Inflation rate (CPI), BI rate, and Balance of Trade as the independent variables. The quantitative methodology is used in this research by applying linear and multiple simple regression techniques. The results of this research show that the Inflation rate, BI rate, and Balance of Trade were significantly affecting the Rupiah exchange rate against the USD, and it found that the most dominant variable in this model was the BI rate. The Inflation rate and Balance of Trade partially had no direct significant influence toward the movement of the Rupiah exchange rate against the USD during the critical anticipation period of Covid-19 pandemic outbreak. Furthermore, Rupiah exchange rate against the USD gave a significant influence toward the IDX Composite index.
\end{abstract}

Keywords: inflation rate, BI rate, balance of trade, IDR/USD exchange rate, IDX composite index, Covid-19 outbreak

\section{Introduction}

The effect of Covid-19 pandemic is truly a global problem because no nation is spared. Countries that rely on tourism, travel, hospitality, and entertainment for their growth are experiencing particularly significant disruptions. Emerging markets and emerging economies face additional challenges with unprecedented capital flow reversals as global risk tolerance declines and currency pressures, thus addressing weakened health systems and creating more restricted fiscal space (Ivanov, 2020). Additionally, in a fragile state with slow growth and high debt rates, many economies joined this crisis. Moreover, the Covid-19 outbreak is considered the greatest crisis since the Great Depression (Gopinath, 2020). The International Monetary Fund (IMF) forecasts that this 2020, over 170 countries, especially developing countries, will experience negative growth in per capita income (Georgieva, 2020). This happens because of the cessation of economic activities. Many states enforce quarantines and social distancing causes the shutdown of many business activities and create uncertainty to all business sectors and the threat of layoffs in corporations.

Covid-19 outbreak positively affecting the Indonesia economy. Figure 1 communicates that the movement trend of Rupiah's value against USD and IDX Composite Index is attenuating. Many economic sectors have decreased very sharply. This condition worsened as the announcement of the first case Covid-19 by the Indonesian government on March $2^{\text {nd }}, 2020$, the value of Rupiah against dollar began drastically depreciated and IDX Composite tend to be collapsed. The value of Rupiah continuously depreciated and even touched sixteen thousand Rupiah level against USD 1.00. While IDX Composite Index was declining quite significant and hit the lowest point $(3,937.63)$ since the 
last two years. This condition is inseparable from the investor sentiment and unpredictability of the global economy, which was hit by the Covid-19 pandemic (Zhang et al., 2020).

The above condition communicates that the fluctuation of the Rupiah was relatively high that it adversely affects to the Indonesian economy. This is disastrous for industries in Indonesia, especially for companies that borrow funds from abroad, they must pay more debts, so that the company's performance will look weak, which will ultimately affect its stock prices (Warjiyo, 2013). The effect of the exchange rate is related to the presence of foreign investors who invest their capital in the Indonesian capital market. Foreign investors are permitted to spend a certain amount of capital on the Indonesia Stock Exchange. Foreign investors will undoubtedly consider the rational factors (inflation rate, interest rate, and trade of balance) of changes in currency exchange rates as the factor in making decisions in investing. The unpredicted events like the Covid-19 pandemic outbreak may significantly affect the stock market returns because of those rational factors. Therefore, this research is to try to understand which factors (the inflation rate, BI rate, and balance of trade) make direct significant impact toward the Rupiah's value against USD and make indirect significant effect toward the Indonesian stock market during the Covid-19 pandemic critical period.

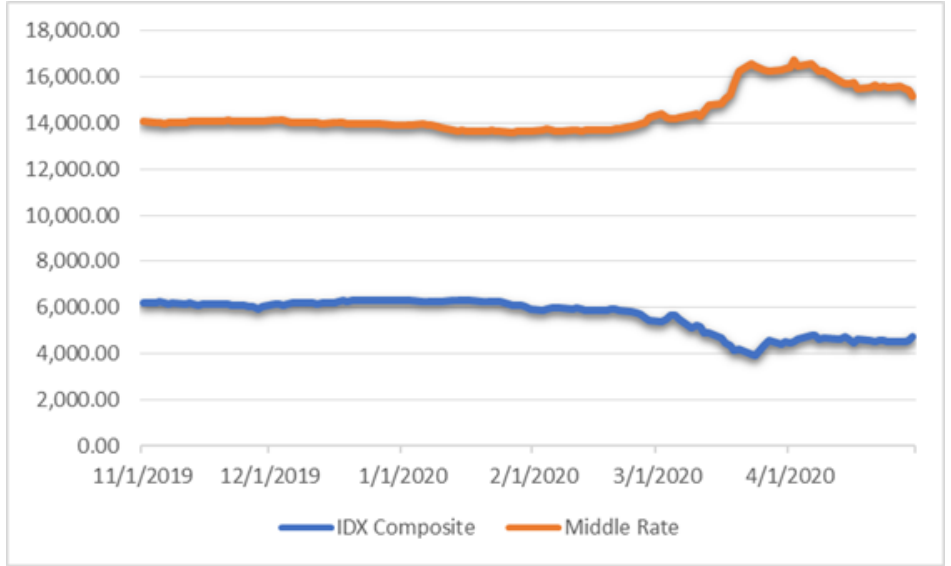

Figure 1. Movement of IDX composite index and middle rate of IDR against USD

Source: Indonesian Stock Exchange \& Bank Indonesia

\section{Literature Review}

\subsection{The Development of Covid-19 Pandemic}

The Covid-19 pandemic outbreak has been considered as a source of frustration for the government and the business world. This pandemic outbreak has been classified as a pandemic disease by World Health Organization (WHO) on February $1^{\text {st }}, 2020$. Covid-19 has been described as an infectious disease caused by a newly discovered type of Coronavirus (World Health Organization, 2020). Furthermore, the spread of Covid-19 is swift. This can be seen from the number of patients of Covid-19 that increases rapidly since the announcement of this virus. As of April 2020, there were 3.233.838 confirmed Covid-19 cases reported to WHO, including 228.525 deaths (World Health Organization, 2020a). The spread is swift because Covid-19 is spreading mainly from indicative individuals to those in close contact through respiratory droplets, through direct contact with infected individuals, or contact with contaminated surfaces and materials. Until now, 216 countries have confirmed various strains of this Coronavirus.

In Indonesia, the Covid-19 case was first discovered in two residents of Depok, West Java, in early March 2020. This is an imported case from Japanese citizens who visited Indonesia for a business trip. It has reported that the patient has the symptom of the virus after direct contact with Japanese citizens in the event at the dance club Paloma \& Amigos in the Jakarta region (Galih et al., 2020). After the announcement of the first case, the Indonesian administration takes some effort to suppress the number of Covid-19 patients. Several regions and provinces in Indonesia enforce a lockdown term called as Large-Scale Social Restrictions.

\subsubsection{Covid-19 and Financial Crisis}

As many countries set restrictions and policies to prevent the spread of Covid-19, it started to weaken the global 
economy, and the financial crisis began to appear in many countries. According to Georgieva (2020), the IMF Managing Director, IMF predicts that more than 170 countries, particularly developing countries, will suffer negative growth in capita income. Covid-19 pandemic crisis is also seen as the biggest crisis since the Great Depression. Covid-19 certainly has disrupted economic activities and create uncertainty in all business sectors. Without a doubt, Covid-19 has messed up the function of financial markets, create the intermediation and transformation of financial assets not smooth, make the financial transactions and economic activities stalled and ultimately cause an overall economic contraction (Ivanov, 2020). Therefore, the current situation of the global economy is falling in a recession cycle. This condition can be seen from the capital market all around the world that already reacted dramatically. The US stock exchange reached the circuit breaker trigger four times in 10 days in March 2020 because the breaker has only ever been activated once since its introduction in 1987 and 1997. Stock prices in Europe and Asia have also plummeted along with the US crash. On its worst day since 1987, FTSE, the UK's broadest index, dropped more than 10 percent by March $12^{\text {th }}, 2020$ (Zhang et al., 2020).

\subsection{IDR Exchange Rate Against USD}

The exchange rate can be used as a measure in assessing the strength of an economy. The exchange rate comunicates how much domestic money is needed to buy one foreign exchange unit (Iba \& Wardhana, 2012). Foreign exchange rates are the price of foreign currency. The exchange rate is determined by the foreign exchange market, which is the market in which various currencies are traded (Rafiq, 2013). Thus, the exchange rate is the ratio between the value of a country's currency with another country's currency or other foreign currencies. In addition, currently, most of the raw materials for companies in Indonesia still rely on imports from abroad. Accordingly, when the IDR (Rupiah) depreciates, this will increase the cost of these raw materials. An increase in production costs will reduce the company's profitability. For investors, the projected decline in earnings will be viewed negatively (Mulhern, 1999). The exchange rate is also one indicator that affects the stock market and the money market because investors tend to be careful about making portfolio investments.

\subsection{IDX Composite Index}

IDX Composite index is one of the stock market indices used by the Indonesia Stock Exchange. IDX Composite index is an index that measures the performance of all the listed companies in the Indonesia Stock Exchange's Main Board and Development Board (IDX, 2020). It was first introduced on April $1^{\text {st }}, 1983$, as an indicator of stock price movements on the JSX (Jakarta Stock Exchange). This index covers the price movements of all common shares and preferred shares listed on the IDX. The stock price index is interpreted as the leading indicator that describes the movement of shares. In the capital market, an index is expected to have five functions, which are: as an indicator of market trends, as an indicator of the level of profit, as a benchmark performance of a portfolio, facilitate the formation of a portfolio with a passive strategy, and facilitate the development of derivative products.

\subsection{Macroeconomic Factors}

\subsubsection{Inflation}

Inflation is a form of economic disease that often arises and is experienced by almost all countries. In general, the definition of inflation is an increase in prices of the goods or services, or it can also be said as a decrease in the purchasing power of the buyer. Bank Indonesia (2020a) stated that inflation is known to be a gradual, constant spike across a broad spectrum of prices. A rise in prices for one or two goods will not be defined as inflation until it extends to (or contributes to) other products. Therefore, the increase in the price of certain goods or the price increase due to a failed harvest, for example, is not included as inflation. The most widely used inflation measures are the Consumer Price Index (CPI) or the cost of living index. This index is based on the price of a package of goods selected and represents consumer spending (Sugema et al., 2010).

\subsubsection{Purchasing Power Parity}

The purchasing power parity (PPP) theory explains the perfect relationship between the relative inflation rates between the two countries and their exchange rates. To be sure, the PPP theory states that the exchange rate balance will adjust to the magnitude of the difference in inflation rates between the two countries (Almasri et al., 2017). Although PPP remains a valuable concept, there is evidence of considerable deviation from the theory's implementation in the real world (Iyke \& Odhiambo, 2017). The purchasing power parity theory also predicts that the decline in the purchasing power of the domestic currency (indicated by an increase in the domestic price level) will be accompanied by a proportional depreciation of its currency in the foreign exchange market (Murad \& Hossain, 2018). 


\subsubsection{Bank Indonesia (BI) Rate}

The Bank Indonesia (BI) rate is an interest rate policy that reflects the stance or monetary policy set by Bank Indonesia and announced to the public. Its implementation of monetary operations carried out by Bank Indonesia through the management of liquidity on the money market to achieve the operational targets of monetary policy (Astuti et al., 2013). BI Rate is a financial policy determined by BI every month preceded by a meeting of the members of the board of governors by looking at the condition of the economy at home and abroad as a whole. The main factor in determining the BI Rate is inflation (Sanica et al., 2018). Prices of goods and services will rise or fall in general and continuously due to rising and falling inflation.

\subsubsection{Balance of Trade}

The balance of trade is a value that characterizes a country's international trade relations. The balance of trade component is the country's exports and imports. According to Waluya (1995) in Marpaung (2013), the balance of trade is a net calculation of export transactions and import transactions of goods (X-M) that are traded (visible trade). The difference between the values of the two components communicates the competitiveness of a country in the field of trade (Rafiq, 2013). If the value of a country's exports is higher than imports, then the (national) currency of that country will be stable and a good sign in terms of the economy. Conversely, if the price of imported goods is higher than the export price, the country can be said to be uncompetitive. If the values are the same, then the country's balance sheet is balanced.

\section{Method}

The method used in this research is a quantitative method. The quantitative approach in this study was conducted to determine the impact of macroeconomic factors that have been driven by the Covid-19 Pandemic toward the depreciation of Rupiah and the collapse of the IDX Composite index. The effect of the Covid-19 outbreak on the value of Rupiah and IDX Composite index will be known through the statistical test of F-test, T-test, and regression analysis. The F-test will be used to validate the entire independent variable model and its association or contribution to the response. The paired T-test will be used to test the significance of the model being tested by seeing the means differences. After that, the regression will be used to examine the correlation between macroeconomics factors (external debt, inflation, BI rate, and balance of trade) toward the value of Rupiah and IDX Composite.

\subsection{Statistical Model}

In this research, there are two statistical models used; they are multiple regression and simple regression models. Furthermore, for the first statistical model, there will be three independent variables: Inflation rate (CPI), BI rate (BR), and Balance of Trade (BoT). Then followed with one dependent variable, which is IDR Exchange Rate against USD (ER) to be tested. The second statistical model will be used to determine the independent model, which is IDR Exchange Rate against USD (ER) and dependent variable, which is the IDX Composite (IDX) index.

Model 1:

$$
\mathrm{ER}_{\mathrm{it}}=\alpha+\beta_{1} \mathrm{CPI}_{\mathrm{it}}+\beta 2 \mathrm{BR}_{\mathrm{it}}+\beta_{3} \mathrm{BoT}_{\mathrm{it}}+\mu_{\mathrm{it}}
$$

Where,

$\mathrm{ER}=$ the exchange rate between Rupiah and USD

$\alpha=$ the intercept

$\beta_{1}, \beta_{2}=$ the coefficient of the variables

$\mathrm{CPI}=$ the inflation

$\mathrm{BR}=$ the $\mathrm{BI}$ rate

$\mathrm{BoT}=$ the balance of trade

$\mathrm{u}=$ error term

This model's objective is to understand the significance of each independent variable above towards the movement of IDR exchange rate against USD.

Model 2:

$$
\mathrm{IDX}=\alpha+\beta \mathrm{ER}+\mu_{\mathrm{it}}
$$

Where,

IDX $=$ the closed price value of all listed Indonesian stock exchange 
$\alpha=$ the intercept

$\mathrm{ER}=$ the exchange rate between Rupiah and USD

$\beta=$ the coefficient of the variables

$\mathrm{u}=$ error term

\section{Results}

\subsection{Classical Assumption Test}

This research utilizes IBM SPSS Statistic Version 24 software to run the data for the required statistical tests. Based on statistical tests that have been done, the results obtained that the classic assumption test results that are normally distributed data, and it means the regression model meets the normality assumption. In addition, the regression model in this study proved to be free of symptoms of multicollinearity, autocorrelation, and heteroscedasticity.

\subsection{Multiple and Simple Linear Regressions Result}

After conducting a classical assumption test, below are the result of multiple and the simple regression test:

Table 1. Model summary of Simple Linear Regression

\begin{tabular}{|c|c|c|c|c|}
\hline Model & $\mathrm{R}$ & R Square & Adjusted R Square & Std. Error of the Estimate \\
\hline 1 & $0.990^{\mathrm{a}}$ & 0.981 & 0.952 & 192.71250 \\
\hline \multicolumn{5}{|c|}{ a. Predictors: (Constant), BoT, CPI, BR } \\
\hline \multicolumn{5}{|c|}{ b. Dependent Variable: ER } \\
\hline Model & $\mathrm{R}$ & R Square & Adjusted R Square & Std. Error of the Estimate \\
\hline 2 & $0.910^{\mathrm{a}}$ & 0.828 & 0.827 & 302.38340 \\
\hline \multicolumn{5}{|c|}{ a. Predictors: (Constant), ER } \\
\hline \multicolumn{5}{|c|}{ b. Dependent Variable: IDX } \\
\hline
\end{tabular}

As seen From Table 1 above, the result for the multiple and simple linear regression is shown. The result indicates that the R-value of Model 1 is 0.990 , which indicates a strong correlation in an overall linear relationship. This interpretation is taken from the $\mathrm{R}$ coefficient rules, which stated: if the value of the determination coefficient is higher than 0.1, it implies that the linear relationship is strong. Furthermore, the researcher also analyses the R-square. The effect of R-square will help illustrate how much the impact of all independent variables on the model's dependent variable. Here, the test resulted that the value of $\mathrm{R}$ square of Model 1 is 0.981 , which indicates that $98.1 \%$ of the Rupiah exchange rate can be described through the Consumer Price Index (CPI), BI rate, and balance of trade. The remaining $1.9 \%$ is then determined by other variables or factors not used in the model.

As for Model 2, the R-value is 0.910 , which also implies a good correlation in an overall linear relation. Furthermore, the analysis of the value of R-square is 0.828 , which means that $82.8 \%$ of IDX Composite index can be represented by the Rupiah exchange rate against the USD. The remaining $17.8 \%$ is then determined by other variables or influences not used in the model.

\subsection{F-Test Result}

The F-test conducted in this study is aimed to determine how much the impact of all independent variables such as inflation rate, BI rate, and balance of trade toward the IDR exchange rate toward USD and this exchange rate toward to IDX Composite index. The result of the F-test can be seen in the Table 2 below. 
Table 2. ANOVA of multiple and simple linear regression

\begin{tabular}{lllllll}
\hline Model & & Sum of Squares & df & Mean Square & F & Sig. \\
\hline $\mathbf{1}$ & Regression & $3,790,642.961$ & 3 & $1,263,547.654$ & 34.023 & $0.029^{\mathrm{b}}$ \\
\cline { 2 - 6 } & Residual & $74,276.214$ & 2 & $37,138.107$ & & \\
\cline { 2 - 6 } & Total & $3,864,919.176$ & 5 & & & \\
\hline
\end{tabular}

a. Dependent Variable: ER

b. Predictors: (Constant), BoT, CPI, BR

\begin{tabular}{lllllll}
\hline Model & & Sum of Squares & df & Mean Square & F & Sig. \\
\hline $\mathbf{2}$ & Regression & $5,3791,871.860$ & 1 & $5,3791,871.860$ & 588.303 & $0.000^{\text {b }}$ \\
\cline { 2 - 7 } & Residual & $11,155,158.030$ & 122 & $91,435.722$ & & \\
\cline { 2 - 7 } & Total & $64,947,029.890$ & 123 & & & \\
\hline
\end{tabular}

a. Dependent Variable: IDX

b. Predictors: (Constant), ER

The result shows that the F-test value in Model 1 is 34.023, while the F-table at the 5\% level communicates a value of 9.16. For this reason, since F-test > F-table where $34.023>9.16$, the null hypothesis (Ho) is rejected, and the alternative hypothesis (Ha) is accepted. Besides that, compare the probability of F-statistics or (Sig.), the probability of the F-test is 0.029. The rule of thumb is F-statistic $<\alpha$, and it means the model is significant. Since it shows that $0.029<0.05$, therefore, it can be concluded that this model 1 of regression is significant. This communicates that the three independent variables together affect the exchange rate of the Rupiah against USD.

As for Model 2, the F-test value is 588.303, while the F-table value at the 5\% level communicates a value of 2.70. Hence, since F-test > F-table where $588.303>2.70$, the null hypothesis (Ho) is rejected, and the alternative hypothesis (Ha) is accepted. Furthermore, compared with the probability of F-statistics or (Sig.), the probability of the F-test is 0.00 . The rule of thumb is F-statistic $<\alpha$, and it means the model is significant. Since it shows that it is $0.00<0.05$, it can be concluded that this model of regression is significant. Thus, the movement of IDR against USD affects the IDX Composite index.

\subsection{T-Test Result}

The T-test is used in this study to calculate the magnitude of the partial correlation, and the intensity of the independent variables determines the dependent variable separately. Therefore, below are rules for the relation between $\rho$-value to the $\alpha$ to check the independent variable, whether it is significant or insignificant toward independent variable:

- If Sig. $\leq \alpha$ or $\mathrm{t}>\mathrm{t}$-table, then reject Ho. This means the independent variable has a significant effect on the dependent variable.

- If Sig $>\alpha$ or $\mathrm{t}<\mathrm{t}$-table, then do not reject/accept Ho. This means that the independent variable does not have a significant influence on the dependent variable.

Therefore, below are there results from each model using IBMS SPSS Version 24.0 software, which consist of T-test and Sig. for each variable: 
Table 3. Coefficients of Multiple and Simple Linear Regression

\begin{tabular}{|c|c|c|c|c|c|c|}
\hline \multirow{2}{*}{\multicolumn{2}{|c|}{ Model }} & \multicolumn{2}{|c|}{ Unstandardized Coefficients } & \multirow{2}{*}{$\begin{array}{l}\text { Standardized Coefficients } \\
\text { Beta }\end{array}$} & \multirow[t]{2}{*}{$\mathrm{t}$} & \multirow[t]{2}{*}{ Sig. } \\
\hline & & B & Std. Error & & & \\
\hline \multirow[t]{4}{*}{1} & (Constant) & $32,828.315$ & $2,976.091$ & & 11.031 & 0.008 \\
\hline & $\mathrm{CPI}$ & -696.905 & $1,044.745$ & -0.105 & -0.667 & 0.573 \\
\hline & BR & $-3,757.938$ & 649.664 & -0.909 & -5.784 & 0.029 \\
\hline & BoT & -0.129 & 0.067 & -0.199 & -1.909 & 0.196 \\
\hline \multicolumn{7}{|c|}{ a. Dependent Variable: ER } \\
\hline \multicolumn{2}{|c|}{ Model } & \multicolumn{2}{|c|}{ Unstandardized Coefficients } & Standardized Coefficients & $\mathrm{t}$ & Sig. \\
\hline \multirow[t]{3}{*}{2} & & B & Std. Error & Beta & & \\
\hline & (Constant) & $16,066.784$ & 431.194 & & 37.261 & 0.000 \\
\hline & ER & -0.722 & 0.030 & -0.910 & -24.255 & 0.000 \\
\hline \multicolumn{7}{|c|}{ a. Dependent Variable: IDX } \\
\hline
\end{tabular}

\subsubsection{T-Test Result of Inflation (CPI)}

$\mathrm{H}_{0}: \beta_{1}=0$, Inflation (CPI) does not have a significant influence on the movement of the IDR exchange rate against USD (ER) during Covid-19 outbreak.

$\mathrm{H}_{1}: \beta_{1} \neq 0$, Inflation (CPI) has a significant influence on the movement of the IDR exchange rate against USD (ER) during Covid-19 outbreak.

According to the rule of the T-Test, to reject $\mathrm{H}_{0}$, the $\rho$-value should less than $\alpha$ or 0.05 . As seen from the Model 1 in Table 3, the value result of $\rho$-value for variable CPI (Inflation) is 0.573 , which means more than the $\alpha(0.05)$. Meanwhile, the result of the t-test value is -0.667 , and the $t$-table value is 4.303 . Therefore, according to the rules above, if t-test $<\mathrm{t}$-table, where $-0.667<4.303$, it can be concluded that the variable is insignificant, and the null hypothesis $\left(\mathrm{H}_{0}\right)$ is accepted while $\mathrm{H}_{1}$ is rejected.

\subsubsection{T-Test Result of BI Rate (BR)}

$\mathrm{H}_{0}: \beta_{1}=0$, BI Rate (BR) does not have a significant influence on the movement of the IDR exchange rate against USD (ER) during Covid-19 outbreak.

$\mathrm{H}_{1}: \beta_{1} \neq 0$, BI Rate (BR) has a significant influence on the movement of the IDR exchange rate against USD (ER) during Covid-19 outbreak.

According to the rule of thumb of the T-Test, to reject $\mathrm{H}_{0}$, the $\rho$-value should less than $\alpha$ or 0.05 . As seen from the Model 1 in Table 3, the value result of $\rho$-value for variable CPI (Inflation) is 0.029 , which means less than the $\alpha$ (0.05). Meanwhile, the result of the t-test value is -5.784 , and the t-table value is 4.303 . For this reason, according to the rules above, if t-test $<\mathrm{t}$-table, where $-5.784>4.303$, it can be concluded that the variable is significant and null hypothesis $\left(\mathrm{H}_{0}\right)$ is rejected while $\mathrm{H}_{1}$ is accepted.

\subsubsection{T-Test Result of Balance of Trade (BoT)}

$\mathrm{H}_{0}: \beta_{1}=0$, Balance of Trade (BoT) does not have a significant influence on the movement of the IDR exchange rate against USD (ER) during Covid-19 outbreak.

$\mathrm{H}_{1}: \beta_{1} \neq 0$, Balance of Trade (BoT) has a significant influence on the movement of the IDR exchange rate against USD (ER) during Covid-19 outbreak.

According to the rules of the thumb of the T-Test, to reject $\mathrm{H}_{0}$, the $\rho$-value should less than $\alpha$ or 0.05 . As seen from the Model 1 in Table 3, the value result of $\rho$-value for variable CPI (Inflation) is 0.196, which means more than the $\alpha$ (0.05). Meanwhile, the result of the $t$-test value is -1.909 , and the t-table value is 4.303 . Therefore, according to the rules above, if t-test $<\mathrm{t}$-table, where $-1.909<4.303$, it can be concluded that the variable is insignificant, and the null hypothesis $\left(\mathrm{H}_{0}\right)$ is accepted while $\mathrm{H}_{1}$ is rejected.

\subsubsection{T-Test Result of Rupiah Exchange Rate Against USD (ER)}

$\mathrm{H}_{0}: \beta_{1}=0$, Rupiah Exchange Rate against USD (ER) does not have a significant influence on IDX Composite index (IDX) during Covid-19 outbreak. 
$\mathrm{H}_{1}: \beta_{1} \neq 0$, Rupiah Exchange Rate against USD (ER) has a significant influence on the movement of IDX Composite (IDX) during Covid-19 outbreak.

According to the rules of the thumb of the T-Test, to reject H0, the $\rho$-value should less than $\alpha$ or 0.05 . As seen from Model 1 in the Table 3, the value result of $\rho$-value for variable Inflation (CPI) is 0.000 , which means less than the $\alpha$ (0.05). Meanwhile, the result of the t-test value is -24.255 and the $t$-table value is -4.303 . For this reason, according to the rules above, if $\mathrm{t}$-test $<\mathrm{t}$-table, where $-24.255>4.303$, it can be concluded that the variable is significant and null hypothesis $\left(\mathrm{H}_{0}\right)$ is rejected while $\mathrm{H}_{1}$ is accepted.

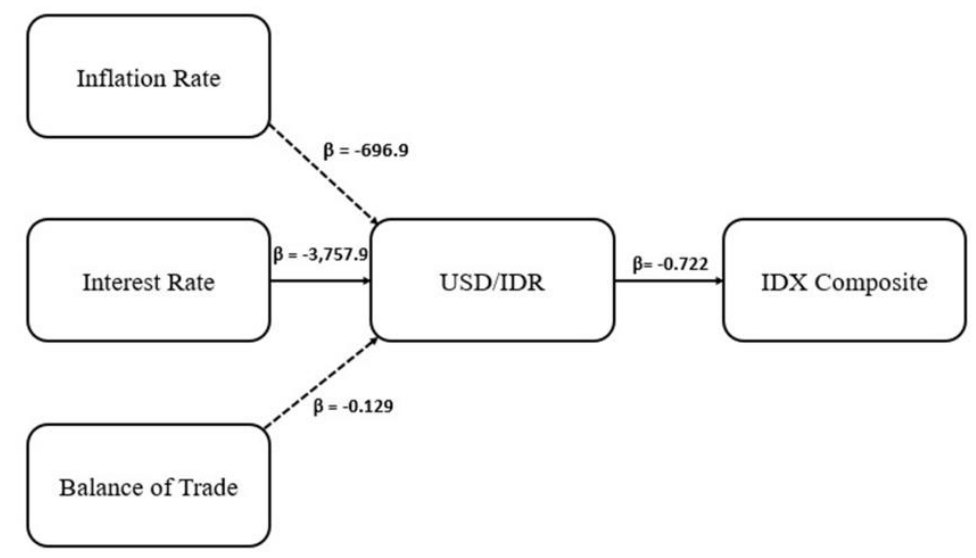

Figure 2. Research model after test result

\section{Discussion}

Theoretically, the relationship between the movement of the inflation rate and the movement of the IDR exchange rate toward the USD is inversely proportional. This means that if the inflation rate increases, the currency will weaken, and vice versa. However, during the Covid-19 outbreak, the result seems different from the theory. The inflation in Indonesia during the Covid-19 pandemic was relatively stable and still controllable. From the T-test result, the Inflation rate variable was partially not significant to influence the movement of the Rupiah exchange rate during the Covid-19 pandemic outbreak. This finding is in-line with prior research conducted by Listika et al. (2019) and Istiqamah \& Septiana, (2018). The study found that inflation has a negative and not significant impact on the exchange rate. Furthermore, it refers to Purchasing Power Parity (PPP) theory, the inflation depends on the purchasing power of everyone. Therefore, during Covid-19, there are two assumptions. First, it can be said that Indonesian has low purchasing power since there are many uncertainties in many economic sectors and layoffs. Second, the availability of sufficient supply so that the influence of inflation from food items, especially volatile foods, is minimal so that the aggregate increase in demand can be met from an increase in supply so that the output gap is very low.

From the T-test result, the BI Rate during the Covid-19 pandemic has a significant impact on the movement of IDR Exchange Rate against USD. BI Rate has a negative sign of influence. This means that a depreciation of the Rupiah will follow a decrease in domestic interest rates. A reduction in BI Rate can cause capital inflows accompanied by a devaluation of the Rupiah. The result is in line with the research conducted by Puspitaningrum (2014) that analyzes to see the significance of BI rate toward the Rupiah exchange rate against USD. Furthermore, during Covid-19, the government can be seen trying to stimulate the economy since they degrade the BI rate. With a decline in BI Rate, it is expected that the foreign investor will invest in Indonesia and triggering Indonesian to consume more to maintain its economic stability.

From the T-test result, Balance of Trade has a negative effect and partially insignificant to influence the movement of the Rupiah exchange rate against USD. This is not in-line with the theory, where the balance of trade is often a factor that can encourage the rise and fall of a country's currency exchange rate. An increase or surplus in the trade balance allows a currency to depreciate. Conversely, a decrease in the value of net exports or a trade balance deficit causes the appreciation of a country's currency. The coefficient of the balance of trade is -0.129 means that the increase in 
the balance of trade causes the value of the Rupiah to depreciate against the US dollar. This result is inversely proportional to the research conducted by Silitonga, Ishak, \& Mukhlis (2019), which stated that net exports had a negative effect and partially significant to influence the movement of the Rupiah exchange rate against USD.

The effect of the Rupiah exchange rate variable on the IDX Composite showed negative and significant results. This indicates that if the Rupiah exchange rate increases (Rupiah depreciates), it will reduce the stock price index, and vice versa. The results of the study are also consistent with the theory, where the portfolio-balance model believes that stock prices negatively affect the exchange rate. The results of this study are compatible with the results of research conducted by Hismendi et al. (2013), and Sudirman (2018) were found that the Rupiah Exchange Rate brought negative and significant influence toward the movement of IDX Composite index. Furthermore, the exchange rate reflects the balance of demand and supply of domestic and foreign currencies/US Dollars. The decline in the Rupiah exchange rate reflects the decline in the international community's demand for the Rupiah because of the declining role of the national economy or because of the increasing demand for foreign currency/US Dollars by the public because of its role as an international payment instrument.

The Indonesian government adopted a comprehensive policy in the fiscal and monetary sectors to deal with Covid-19. In the financial area, the government has implemented a policy of refocusing activities and a budget reallocation. For this reason, the Indonesian political leader issued Presidential Instruction No.4 Year 2020, instructing all Ministers/Leaders/Governors/Regents/Mayors to accelerate refocusing activities, budget reallocation, and procurement of goods and services for Covid-19 handling.

In the monetary sector, a monetary policy taken must be aligned with fiscal policy in minimizing the impact of Covid-19 on the national economy. Therefore, the monetary authority must be able to maintain the Rupiah exchange rate, control inflation, and provide a monetary stimulus for the business world. It is hoped that there will be relaxation in bank lending and intensifying the distribution of People's Business Credit (KUR). BI has issued a monetary stimulus policy through a triple intervention policy and lowered the mandatory minimum reserve requirement ratio for conventional commercial banks. BI decided to keep the BI 7-Day Reverse Repo Rate (BI7DRR) at $4.50 \%$, the Deposit Facility interest rate at 3.75\%, and the Lending Facility interest rate at $5.25 \%$. This decision considers the need to maintain exchange rate stability amid the uncertainty of global financial markets. However, Bank Indonesia sees room for a fall in interest rates in-line with low inflationary pressures and the need to boost economic growth.

\section{Conclusion}

In general, the results of this study can be drawn several conclusions. From the first model, it can be concluded that the inflation rate, BI rate, and balance of trade together simultaneously affect the movement of IDR against USD during the Covid-19 pandemic. However, BI rate is the only independent variables that partially has a significant effect on the movement of IDR against USD during the Covid-19 pandemic. Meanwhile, as for the second model, there is a significant correlation between IDR exchange rate against USD and IDX Composite. Based on the results of the F-Test and T-Test, it is found that there is a significant relationship between IDR exchange rate against USD and IDX Composite during the critical initial stage period of Covid-19 outbreak. Furthermore, viewed from policies created to overcome the Covid-19, the effectiveness of macroeconomic policies can be seen through monetary and fiscal policies. The fact is that handling the impact of Covid-19 pandemic in terms of economies is like having a two-edged sword. In short term period, the most important thing is to restore health holistically so that it can become a state defense. At another side, sacrificing the short-term for the sake of the whole industry to gain long-term benefits might be more relevant in-order to maintaining the economic stability in general.

\subsection{Recommendations}

\subsubsection{Government}

Learning from the bitter experience of the debt crisis, the government must be careful in attracting funding by looking for sources of financing that have the smallest risk. The withdrawal of foreign loans and the issuance of foreign currency bonds are especially vulnerable to global pressures and exchange rate fluctuations. The government cannot face this crisis alone, so it needs support and criticism from all parties. Bank Indonesia, as the monetary authority, must balance fiscal stimulus with easing macro prudential policies. Whereas the Indonesian Financial Services Authority (OJK), lest relaxation of credit rules neglect its main task as supervisors of bank operations and non-bank financial institutions. Finally, everyone never knows what the future will be like because of the crisis that happened today, no one can predict it. Therefore, a sense of crisis must be built and become the foundation in the preparation of the Indonesian State Budget. One lesson to be learned from the economic crisis is the importance of 
maintaining fiscal management that prioritizes prudence, soundness, and sustainability. This research also communicates the seriousness of Indonesia government in facing the impact of the crisis. The result communicates that maintaining communication and coordination among financial stakeholders in Indonesia is a key element point. It will help the government to finding best solution in overcoming the crisis.

\subsubsection{Banking}

Several business sectors were affected by the coronavirus pandemic outbreak (Covid-19), including the banking sector. Therefore, banks must carefully mitigate risk and use creative strategies to deal with the current uncertain conditions. Banks must have a new navigation map to be able to face the current crisis. The debtor mapping process for the restructuring process must proceed immediately and clearly so that the bank's cash flow is visible after treatment. For this reason, banks can revise the Bank's Business Plan regarding the effect of the Covid-19 pandemic. Banks also must focus on industries that are prospects to be funded. Banks must be selective in choosing which business sector is attractive and have good growth during the Covid-19 outbreak. According to Dcode EFC research (2020), the business sectors (potential winners) are the sectors in agribusiness, telecommunications, e-commerce retailing, pharmaceuticals, cleaning products \& medical devices.

\subsubsection{Investors}

The investors could use the result of this research to analyze and make the decision toward the market conditions of Indonesia during the Covid-19 pandemic. The investors can see the pattern of the financial crisis from the result of this research. Furthermore, it is expected for investors not to rush in deciding the conditions of the global markets. Investors could consider the efforts given by the government to create a better and stable economy. This research is also capable to develop mutual understanding and communication for the investors. They can develop a strong information about market conditions in Indonesia and establishing mutual communication with related mutual counterparts.

\subsubsection{Academic}

For future research on the same subject, it is suggested that the data be richer and more varied than what was used in this research to obtain a more objective and reliable outcome. Besides that, this study only focuses on the macroeconomics variables internally. Hence, it is also recommended for future research to consider the other macroeconomics variables internally and externally. For example, current account deficit, foreign exchange reserves, external debt, FED rate, Dow Jones Index, and Shanghai SE composite index. Finally, it is also worth mentioning this research will be a supporting tool among researchers to coordinate and communicate in discussing the updated conditions on the impact of the Covid-19 pandemic towards the country's economic. Hopefully in the future a strong and integrated financial concept can be made to create better economic conditions.

\subsection{Limitations}

There are some limitations of this research. Firstly, this research is exploring limited variables that affect IDR against USD or IDX composite index, such as Inflation Rate (CPI), BI Rate (BR), and Balance of Trade (BoT). Thus, the results are limited to those specific characteristics. Secondly, this research analyzes the impact of the data variables generated in November 2019 to April 2020 period. For this reason, the outcomes and methodology of this research can be used and developed further to evaluate the implications for the critical period of the performance of Rupiah against USD and finally the IDX composite index.

\section{References}

Almasri, A., Månsson, K., Sjölander, P., \& Shukur, G. (2017). A wavelet-based panel unit-root test in the presence of an unknown structural break and cross-sectional dependency, with an application of purchasing power parity theory in developing countries. Applied Economics, 49(21), 2096-2105. https://doi.org/10.1080/00036846.2016.1231908

Astuti, R., Susanta, H., \& Apriatni. (2013). Analisis Pengaruh Tingkat Suku Bunga (SBI), Nilai Tukar (Kurs) Rupiah, Inflasi, dan Indeks Bursa Internasional Terhadap IHSG [In Indonesia language: Analysis of The Effect of Interest Rate (SBI), Rupiah Exchange Rate, Inflation, and International Stock Exchange Index Toward IHSG]. Diponegoro Journal of Social and Politic of Science, 2(4), 1-10.

Bank Indonesia. (2020). Definition to Inflation - Bank Sentral Republik Indonesia. Retrieved May 17, 2020, from https://www.bi.go.id/en/moneter/inflasi/pengenalan/Contents/Default.aspx

Galih, B., Sari, H. P., \& Maharani, T. (2020, March 9th). Kronologi dan Urutan Munculnya 6 Orang Positif Virus Corona di Indonesia [In Indonesia language: Chronology and Order of 6 People with Coronavirus Positive in 


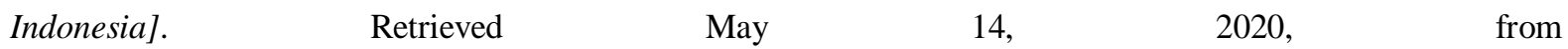
https://nasional.kompas.com/read/2020/03/09/05280011/kronologi-dan-urutan-munculnya-6-orang-positif-virus -corona-di-indonesia?page $=1 \% 5 \mathrm{C}$

Georgieva, K. (2020, May 9th). Confronting the crisis: priorities for the global economy. Retrieved May 14, 2020, from https://www.imf.org/en/News/Articles/2020/04/07/sp040920-SMs2020-Curtain-Raiser

Gopinath, G. (2020, May 14th). The great lockdown: worst economic downturn since the great depression-IMF Blog. Retrieved May $14, \quad 2020, \quad$ from https://blogs.imf.org/2020/04/14/the-great-lockdown-worst-economic-downturn-since-the-great-depression/

Hismendi, H. A., \& Musnadi, S. (2013). Analisis Pengaruh Inflasi, Nilai Tukar Rupiah, Dan Suku Bunga SBI Terhadap Pergerakan Indeks Harga Saham Gabungan Di Bursa Efek Indonesia [In Indonesia language: Analysis of the Effect of Inflation, Rupiah Exchange Rate, and SBI Interest Rates on the Movement of the Composite Stock Price Index in The Indonesia Stock Exchange]. Ekonomikawan: Jurnal Ilmu Ekonomi Dan Studi Pembangunan, 1(2), 16-28. https://doi.org/10.30596/ekonomikawan.v16i2.945

Iba, Z., \& Wardhana, A. (2012). Pengaruh Inflasi, Suku Bunga SBI, Nilai Tukar Rupiah Terhadap USD, Profitabilitas, Dan Pertumbuhan Aktiva Terhadap Harga Saham Perusahaan Pembiayaan Di Bursa Efek Indonesia [In Indonesia language: The Effect of Inflation, SBI Interest Rates, Rupiah Exchange Rate Against USD, Profitability, and Asset Growth on Stock Prices of Financing Companies on The Indonesia Stock Exchange]. Jurnal Kebangsaan, 1(1), 1-6.

IDX. (2020). Indonesia Stock Exchange. Retrieved May 17, 2020, from https://www.idx.co.id/en-us/products/index/

Istiqamah, \& Septiana, H. A. (2018). Pengaruh Inflasi dan Suku Bunga Terhadap Nilai Tukar Rupiah Pada Dollar Amerika [In Indonesia language: The Effect of Inflation and Interest Rates on the Exchange Rate of the Rupiah on the US Dollar]. Jurnal Spread, 8(1), 19-30.

Ivanov, D. (2020, March). Predicting the impacts of epidemic outbreaks on global supply chains: A simulation-based analysis on the coronavirus outbreak. Transportation Research Part E, 136, 101922. https://doi.org/10.1016/j.tre.2020.101922

Iyke, B. N., \& Odhiambo, N. M. (2017). Foreign exchange markets and the purchasing power parity theory: Evidence from two Southern African countries. African Journal of Economic and Management Studies, 8(1), 89-102. https://doi.org/10.1108/AJEMS-03-2017-147

Listika, N., Asngari, I., \& Suhel, S. (2019). Pengaruh inflasi dan capital inflow terhadap nilai tukar: Studi kasus Indonesia-Malaysia [In Indonesia language: The effect of inflation and capital inflow on exchange rates: A case study of Indonesia-Malaysia]. Jurnal Ekonomi Pembangunan, 16(1), 19-26. https://doi.org/10.29259/jep.v16i1.8874

Marpaung, E. (2013). Pengaruh Nilai Tukar Riil Terhadap Trade Balance di Negara ASEAN (Pendekatan Kondisi Marshall-Lerner dan Fenomena J-Curve) [In Indonesia language: The Effect of Real Exchange Rates on Trade Balance in ASEAN Countries (Marshall - Lerner Condition Approach and J-Curve Phenomenon)]. Economic Development Analysis Journal, 2(3), 46-60.

Mulhern, F. (1999). Customer Profitability Analysis: Measurement, Concentration and Research Directions. Journal of Interactive Marketing, 13(1), 25-40. https://doi.org/10.1002/(SICI)1520-6653(199924)13

Murad, S. M. W., \& Hossain, M. A. (2018). The ASEAN experience of the purchasing power parity theory. Financial Innovation, 4(1), 1-10. https://doi.org/10.1186/s40854-018-0113-1

Puspitaningrum, R. (2014). Pengaruh Tingkat Inflasi, Tingkat Suku Bunga Sbi, dan Pertumbuhan Ekonomi terhadap Nilai Tukar Rupiah Studi pada Bank Indonesia Periode Tahun 2003-2012 [The Influence of Inflation Rate, Sbi Interest Rate, and Economic Growth on the Rupiah Exchange Rate Study at Bank Indonesia 2003-2012]. Jurnal Administrasi Bisnis S1 Universitas Brawijaya, 8(1), 79644.

Rafiq, S. (2013). Sources of time-varying trade balance and real exchange rate dynamics in East Asia. Journal of the Japanese and International Economies, 29, 117-141. https://doi.org/10.1016/j.jjie.2013.06.001

Sanica, I. G., Nurcita, I. K., Mastra, I. M., \& Sukarnasih, D. M. (2018). Effectiveness and Forecasting of Interest Rate Reversal BI 7-Day Repo Rate in Indonesia: Lower Bound on Monetary Policy?. Mediterranean Journal of Social Sciences, 9(1), 171-180. https://doi.org/10.2478/mjss-2018-0016

Silitonga, R., Ishak, Z., \& Mukhlis, M. (2019). Pengaruh ekspor, impor, dan inflasi terhadap nilai tukar Rupiah di 
Indonesia [In Indonesia language: The influence of exports, imports, and inflation on the Rupiah exchange rate in Indonesia]. Jurnal Ekonomi Pembangunan, 15(1), 53-59. https://doi.org/10.29259/jep.v15i1.8821

Sudirman, S. (2018). Pengaruh Perubahan Nilai Tukar Rupiah Tengah US Dollar Terhadap Indeks Harga Saham Gabungan (IHSG) Di Bursa Efek Indonesia [In Indonesia language: The Effect of Changes in the US Dollar Middle Rupiah Exchange Rate on the Composite Stock Price Index (IHSG) in the Indonesia Stock Exchange]. Al-Buhuts E-Journal, 14(1), 1-17. https://doi.org/10.30603/ab.v14i01.412

Sugema, I., Iqbal Irfany, M., Holis, A., \& Bakhtiar, T. (2010). Consumer price index for the poor (CPI-P): An empirical analysis of Indonesia. International Research Journal of Finance and Economics, 58, 58-64.

Waluya, H. (1995). Ekonomi Internasional [In Indonesia language: International Economics]. Jakarta: PT. Rineka Cipta.

Warjiyo, P. (2013). Indonesia: stabilizing the exchange rate along its fundamental. BIS Papers, 73, 177-187.

World Health Organization. (2020). Q\&A on coronaviruses (COVID-19). Retrieved from https://www.who.int/news-room/q-a-detail/q-a-coronaviruses\%0AContents

World Health Organization. (2020a). Coronavirus disease 2019 (COVID-19) Situation Report - 71 (Vol. 14). https://doi.org/10.1213/xaa.0000000000001218

Zhang, D., Hu, M., \& Ji, Q. (2020, March). Financial Markets Under the Global Pandemic of Covid-19. Finance Research Letters, 101528. https://doi.org/10.1016/j.frl.2020.101528

\section{Copyrights}

Copyright for this article is retained by the author(s), with first publication rights granted to the journal.

This is an open-access article distributed under the terms and conditions of the Creative Commons Attribution license (http://creativecommons.org/licenses/by/4.0/). 